\title{
India's Information Technology Industry: A Tale of Two Halves
}

\author{
Biswajit Dhar and Reji K. Joseph
}

\begin{abstract}
This chapter provides an account of the development of the information technology (IT) and information technology-enabled services (ITES) in India. The IT sector was developed from the early 1960s, wherein only the government-owned companies were allowed to operate in this sector. In the later decades, the industry was opened to the private sector, both Indian and foreign. There is, however, no evidence that this open-door policy helped the IT industry to develop.

In contrast, the ITES sector received a major boost when Indian private companies took advantage of the increasing demand for these services towards the end of the previous millennium. Subsequently, the ITES have expanded phenomenally, establishing India as one of the ITES powerhouses of the world. Although India's ITES sector was an unqualified success, there is not much evidence that this sector, or its hardware counterpart, contributed to indigenous technology development. India's R\&D spending remained sluggish, which remains a major source of concern.

A major uncertainty faced by the R\&D system arose from India's patent regime. The amendment of India's patent law undertaken in the year 2000 to bring it in conformity with the TRIPS Agreement excludes "computer programme per se" from patenting. Initially, there was lack of clarity about the interpretation of the phrase. Later, the Controller General of Patents, Designs and Trademarks, the authority responsible for implementing Patents Act, 1970, and
\end{abstract}

B. Dhar $(\bowtie)$

Centre for Economic Studies and Planning, School of Social Sciences, Jawaharlal Nehru University, New Delhi, India

R. K. Joseph

Institute for Studies in Industrial Development, New Delhi, India

e-mail: rejikjoseph@isid.org.in 
the Judiciary have both provided a degree of clarity as to what "computer programme per se" really means.

\section{Keywords}

Information technology $\cdot$ Information technology-enabled services $\cdot$ Electronics

- Software · Outsourcing $\cdot$ Patents $\cdot$ R\&D

\section{Introduction}

Since the end of the previous millennium, India has been able to establish itself as a major player in the information technology-enabled services (ITES). In 1999-2000, India's exports of software services ${ }^{1}$ were just less than US\$ 3 billion, which had expanded to nearly US $\$ 100$ billion by $2016-2017 .{ }^{2}$ WTO informs us ${ }^{3}$ that in 2015 , India's exports of computer services were nearly $16 \%$ of global exports.

While the ITES segment of the Information Technology (IT) sector has performed exceptionally well, the other component of the industry, the Indian computer electronics industry, has not been able to establish itself as a distinct entity, despite its emergence in the early 1960s. The IT sector is, therefore a tale of two contrasting halves in terms of their performances.

This contrast notwithstanding, there is a common thread that runs through the performances of the two segments of the IT industry, and this is the role of policy. While the computer electronics industry was sought to be established through a series of policy initiatives, the ITES sector, too, depended on government's policy support, even though the trigger for its growth was provided by the market forces, in particular the global market conditions at the turn of the millennium. Given the overwhelming presence of "policy" determining the growth of the IT industry, it seems hardly surprising that neither segment of the industry was driven by continuous process of innovations. Thus, the dynamics of the Indian IT industry has been remarkably different from those of the global hubs of the industry, where the innovation systems together with intellectual property regimes have played decisive roles in driving their growth.

This chapter has three parts: the first discusses the evolution and the subsequent developments in the computer electronics industry, the second discusses the performance of the ITES sector, and the third discusses the approach towards patenting of computer-related innovations (CRIs). The discussion in the final part reflects the ambivalence of the policy makers in deciding on the patent regime appropriate for CRIs.

\footnotetext{
${ }^{1}$ Software service includes IT services exports and exports on account of Business Process Outsourcing (BPO). RBI (2010).

${ }^{2}$ RBI (2017).

${ }^{3}$ Authors' calculations from WTO Statistics Database; figures for computer services do not include data for BPO activities.
} 


\section{The Computer Electronics Industry in India}

\subsection{Triggering the Development of the Industry}

The seeds of the Indian electronics industry were sown by the Electronics Committee set up in 1963. The Committee, better known as the "Bhabha Committee", ${ }^{4}$ gave a 10-year (1966-1975) roadmap for building domestic capacities for the manufacture of computers and components. Its recommendations for the components sub-sector were that domestic manufacturing should focus on producing in large quantities in order to reap the economies of scale and that adequate research and development support was made available to the manufacturing units in order to keep them abreast with the advances in technology in this highly dynamic industry. Immediately after the Bhabha Committee submitted its report, the government constituted another Electronics Committee under the chairmanship of Vikram Sarabhai, the doyen of the Indian space programme. The Sarabhai Committee was tasked to take account of the most urgent needs of the electronics industry, to keep track of the research being done in design and development and to give guidance and direction, where necessary, identify sectors where indigenous production could be built up, and promote the speedy building up of such capacity. ${ }^{5}$

Armed with the recommendations of the two Committees, the government initiated the process of building a self-reliant electronics industry in the country. The Department of Electronics (DoE) was established in 1970 and in the following year, the Electronics Commission was set up to lay down policies and to guide the future development of the electronics industry in India. The thrust of the policies adopted since the early 1970 s was to promote a state-led electronics sector, with the involvement of both the Central government as well as the state governments.

Bhabha Committee's emphasis on the development of an indigenous computer industry and the endorsement of this view by the Sarabhai Committee, led to the establishment of computer production facilities in the public sector. The Electronics Corporation of India Limited (ECIL) was already in existence since 1967 under the Department of Atomic Energy (DAE) and was entrusted to commercialise electronic systems developed at the Atomic Research Centre under the Department. By 1971, ECIL became a computer manufacturing enterprise that was fully supported by the DoE. ${ }^{6}$

The 1970s was marked by government's resolute pursuit of developing local expertise in the computer industry. This endeavour had two distinct phases. In the first phase which lasted until the middle of the decade, the clear emphasis was on giving the ECIL the status of the dominant firm in the emerging domestic industry. This strategy was strongly endorsed by the Minicomputer Panel, a study group set up by the Electronics Commission in $1974,{ }^{7}$ which concluded that ECIL would be

\footnotetext{
${ }^{4}$ Agarwal (1985), p. 283.

${ }^{5}$ Agarwal (1985), p. 283.

${ }^{6}$ The following account is taken from, Rajaraman (2012).

${ }^{7}$ Brunner (1991), p. 1742.
} 
able to meet domestic demand for minicomputers, both in terms of production and technology. Having satisfied itself that small computer systems could be designed and assembled in India on the basis of imported components and peripherals, the government initiated a variety of policies to support the fledgling industry. ${ }^{8}$

However, the government's schema of putting ECIL as the lead firm in the Indian industry had, at best, mixed results. Rajaraman points out the company had two sets of weaknesses": the company "worked more like a cottage industry" and its sales efforts being poor, and the company was unable to find ready markets for its products. ECIL mostly served a captive market that included government departments and agencies like the atomic energy establishments and universities funded by the government. According to Brunner, "by about 1976, it had become obvious that ECIL was not able to meet domestic computer demand with competitive prices and technology". These two factors combined together, increased the gap between the demand and supply of computers in the country. ${ }^{10}$

These were compelling reasons for the government to open the doors for increased private sector participation in the computer industry. The turnaround on the part of the government came in 1978 with the announcement of the Minicomputer Policy, which opened up the hitherto restricted area of computers to private sector companies. The government relaxed the norms for obtaining industrial licences, which facilitated the entry of three private sector enterprises in the industry. ${ }^{11}$ Before the turn of the decade, a fourth company had also started operations (Table 1). ${ }^{12}$

\subsection{Facilitating the Growth of the Electronics Industry in the 1980s}

In the 1980s, the emphasis shifted to encouraging the private sector to play a pivotal role through a number of key innovation-boosting initiatives.

The New Electronics Policy (NEP) unveiled in January 1984 had four main objectives: (i) facilitating technology transfer in the electronics industry, (ii) import of computers for government departments, (iii) establishing "science cities"/science parks to encourage expatriate Indian technicians to return to the country, and (iv) setting up free trade Export Processing Zones.

\footnotetext{
${ }^{8}$ Grieco (1982).

${ }^{9}$ Rajaraman (2012), p. 25.

${ }^{10}$ Brunner (1991), p. 1742.

${ }^{11}$ These companies were Hindustan Computers Limited (HCL), a joint venture between a private Indian firm and the Uttar Pradesh state government; DCM Dataproducts (DCM), a subsidiary of Delhi Cloth Mills and Operations Research Group (ORG), a subsidiary of Sarabhai Enterprises. See, Grieco (1982), p. 614.

${ }^{12}$ The fourth Indian enterprise was the International Data Machines (IDM, founded by former IBM employees with the assistance of IBM), which marketed and serviced a microsystem designed and assembled by the Indian firm National Radio and Electronics Company, a subsidiary of Tata Enterprises.
} 


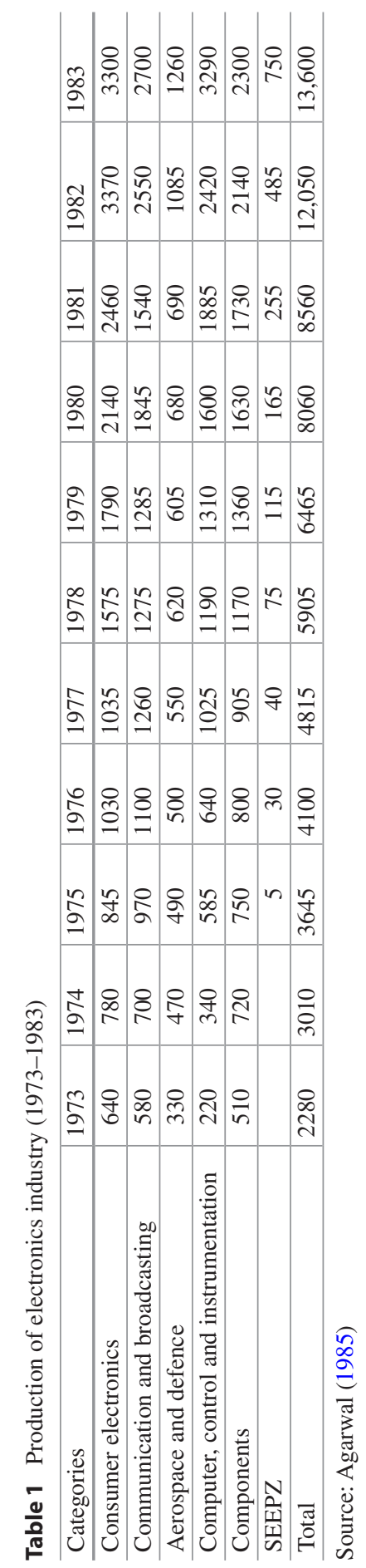


A New Computer Policy (NCP) was announced in 1984 for removing the institutional barriers to "transforming the industry into a 'virtuous circle' of competitive prices/costs-higher demand-higher scale of production-higher efficiencycompetitive prices/costs". It marked a departure from the erstwhile policy that restricted entry of companies that were part of "monopoly houses"13 and those that were covered by the Foreign Exchange Regulation Act (FERA). Imports of technology and capital goods were liberalised, and although domestic manufactures were initially given import protection from competitors of similar products, they were progressively exposed to international competition.

The NEP and NCP introduced policies markedly different from the policies in the 1970s; the key departure was the freedom given to the private sector to drive the industry. Simultaneously, existing public sector organisations were strengthened, and new institutions like the Centre for Development of Advanced Computing (C-DAC) Technology Development Council and Centre for Development of Telematics (C-DoT) were established to expand the domestic capabilities in the electronics sector.

\subsection{Technology Imports and Domestic R\&D Behaviour}

The leverage of foreign firms in the Indian electronics industry declined in the 1970s. The share of these firms in domestic production declined from 10\% to $3 \%$ between 1972 and 1977. However, the participation of foreign firms increased in the later 1970s through strategic alliances and collaborations, which increased from 16 in 1977 to 210 in 1985. Technology was increasingly sourced from four major countries: the USA, Japan, West Germany and the UK.

The data for the Indian electronics industry during the liberalisation phase (the 1980s) shows low bargaining power of Indian firms (no definite trends, the cases involving both lump sum payment and royalty), royalty rates close to $5 \%$ and increase in the proportion of cases with higher lump sum payments (the share of cases with lump sum payments exceeding Rs. 5 million were 6\% in 1982 and 29\% in 1991). It resulted in the increase of cost of technology per collaboration and more foreign exchange outflows.

\subsubsection{Domestic R\&D Behaviour: C-DAC and Param Supercomputer}

As regards domestic R\&D, organisations like Technology Development Council, C-DoT, C-DoM and C-DAC were responsible for technology development on behalf of DoE. Agencies like Defence Research and Design Organisation (DRDO) and Council of Scientific and Industrial Research (CSIR) also undertook R\&D activities in electronics. But R\&D sponsored by the government was "not linked to

\footnotetext{
${ }^{13}$ In 1969, the Monopolies and Restrictive Trade Practices Act was enacted to control the growth of "monopoly houses". The Indian corporate sector was then dominated by the so-called monopoly houses or business groups. The expressed intent of the legislation was to curb concentration of corporate power.
} 
the manufacturing system in the country, and hence the outcome of the R\&D activities of these organisations remained mostly unutilised".

Denial of supercomputers to India by the USA and Japan led to the development of indigenous supercomputers, which remains as the most successful R\&D foray by an Indian enterprise. The countries of Western alliance had established a strict regime for the export of electronic items citing "dual uses", i.e. those that could be employed both for civilian and defence-related purposes. Exports of these items were regulated by the Coordinating Committee for Multilateral Export Controls (CoCoM). Indeed, this Cold War mechanism affected India, a traditional ally of the Soviet Union.

The DoE established the C-DAC with an initial investment of Rs. 300 million to build high-performance computers. The project was successfully completed in 1991, and the Param supercomputer was unveiled. From its very first generation, Param supercomputer was ranked among the best machines in the world. ${ }^{14}$

\subsection{Electronics Industry in the Period of Economic Reforms}

Since 1991, the key reforms benefiting the electronics sector were elimination of tariffs on IT products, abolition of industrial licencing system ${ }^{15}$ and dropping of entry barriers for FDI.

In 1991, the telecom sector was fully opened for FDI. Five leading multinational companies (MNCs) set up their manufacturing facilities in India - Alcatel, Lucent Technologies, Ericsson, Siemens and Fujitsu. When the de-licencing of telecom services was notified in 1999, the demand for telecom equipment moved in favour of cellular mobile and internet services. This shift away from fixed switches benefitted the global players. ${ }^{16}$

Impact of opening up of this sector for FDI had only a limited impact. The study conducted by Rao and Dhar showed that the "realistic FDI" in the electronics sector were quite small, including office, accounting and computing machinery; radio, television and communication equipment; and medical, precision optical instruments and watches. ${ }^{17}$ Francis concludes that the Information Technology Agreement of 1997 (ITA-1) did not help in attracting FDI into this sector. Ernst points out that during 2010 and 2013, FDI inflows into the electronics sector was "extremely low": it ranked 24 out of 26 sectors in terms of cumulative FDI during this period. ${ }^{18}$

However, Mrinalini et al. points out that software and IT is the second leading sector in terms of FDI inflows. Out of the total FDI inflow of US\$350.47bn during 2003-2009, 13.8\% was into the software and IT sector. In terms of FDI in R\&D,

\footnotetext{
${ }^{14}$ Rajaraman, History of Computing in India (1955-2010), 2012, p. 37; Karunakaran, God, Man and Machine, 2009.

${ }^{15}$ Industrial licences for the consumer electronics were done away with in 1996 (Ernst 2014).

${ }^{16}$ Francis (2016).

${ }^{17}$ Rao and Dhar, The Tenuous Relationship between Make in India and FDI Inflows 2016, p. 3.

${ }^{18}$ Ernst (2014).
} 
Table 2 Details of FDI inflow during the period 2003-2009

\begin{tabular}{l|l|l}
\hline & FDI inflow (US\$bn) & FDI in R\&D (US\$bn) \\
\hline Total & $\$ 350.5$ & $\$ 29.2$ \\
\hline In software and IT & $\$ 48.3$ & $\$ 14.7$ \\
\hline Share of total inflows & $13.8 \%$ & $50.4 \%$
\end{tabular}

Source: Computed and compiled by authors based on Mrinalini et al. (2013)

Table 3 Details of patents obtained by MNCs having R\&D centres in India

\begin{tabular}{|c|c|c|c|c|}
\hline & $\begin{array}{l}\text { Number } \\
\text { of firms }\end{array}$ & $\begin{array}{l}\text { Number of Indian } \\
\text { patents granted for } \\
\text { MNCs with R\&D } \\
\text { centres in India }\end{array}$ & $\begin{array}{l}\text { Global patents } \\
\text { granted for MNCs } \\
\text { with R\&D centres } \\
\text { in India }\end{array}$ & $\begin{array}{l}\text { Indian patents as } \\
\text { percentage of } \\
\text { global patents }\end{array}$ \\
\hline $\begin{array}{l}\text { FDI in R\&D } \\
\text { firms }\end{array}$ & 74 & 1166 & 214,686 & $0.5 \%$ \\
\hline $\begin{array}{l}\text { FDI in R\&D } \\
\text { firms in } \\
\text { software and } \\
\text { IT }\end{array}$ & 54 & 749 & 129,385 & $0.6 \%$ \\
\hline $\begin{array}{l}\text { Software and } \\
\text { IT (share of } \\
\text { total) }\end{array}$ & $72.9 \%$ & $64.2 \%$ & $60.3 \%$ & \\
\hline
\end{tabular}

Source: Compiled by Authors based on Mrinalini et al. (2013)

this sector received more than half of the inflow. Out of the FDI in R\&D, more than $50 \%$ was into this sector (Table 2). ${ }^{19}$

Outcomes of FDI in R\&D are significant. Mrinalini et al. (2013) find that out of 706 firms, companies investing in FDI in R\&D in India, only 74 have obtained Indian patents, taking up $0.5 \%$ of their global patents. Of these firms, 54 were in software and IT sector (Table 3).

It is found from the above table that FDI in R\&D firms in India have negligible share of patents in India as compared to their global patent profile. Mrinalini et al. (2013), however, have not gone into the factors contributing to this phenomenon.

\subsection{Manufacturing}

Government of India estimated that in India, demand for electronic products in 2008-2009 was about US\$45 billion, while domestic production was only about US $\$ 20$ billion. Projections for the year 2020 showed that the demand would be US $\$ 400$ billion, while domestic supply would be only US $\$ 100$ billion, indicating a substantial demand-supply gap. In electronics hardware production, India's share was only $1.3 \%$ of the global production in 2011, with imports accounting for $64 \%$ of India's consumption of electronic products and 51\% of electronic components. ${ }^{20}$

\footnotetext{
${ }^{19}$ Mrinalini et al. Foreign Direct Investment in R\&D in India, 2013, p. 769.

${ }^{20}$ Ernst, Upgrading India's Electronics Manufacturing Industry, 2014, p. 2.
} 
Ernst argues that India's production base for components was declining. For example, printed circuit boards (PCBs) accounted for $90 \%$ of the cost of strategically important telecom equipment production, and two-thirds of its $\mathrm{PCB}$ requirements were met through imports. India's share in world PCB production was only $0.7 \%$. While the liberalisation of telecom services boosted demand for electronic products, it did not result in an increased opportunity for domestic manufactures but came as an opportunity for foreign companies. ${ }^{21}$

Ernst identified three major challenges facing India: (i) lack of a vibrant domestic component industry ${ }^{22}$; (ii) disconnect between manufacturing and design capabilities; and (iii) a broken innovation system.

Elaborating on the second challenge, Ernst pointed out that India had acquired capabilities in integrated circuit (IC) designs, but most of the IC design work done in India was for MNCs, which were transferred to their manufacturing location in other countries, especially in China. IC design capabilities in India were not linked to manufacturing in India. Moreover, investment in R\&D in India was at a very low level, below $1 \%$ of GDP. Larger foreign companies were reluctant to invest in fullscale manufacturing $R \& D$ in India. The foreign original equipment manufacturers typically conducted only the final assembly here.

The table below summarises the key facets of major non-government companies operating in India's IT and ITES sectors (Table 4). ${ }^{23}$

The main area of concern, in our view, is that the R\&D spending of the industry still remains at a relatively low level. R\&D spending increased nearly sevenfold between 2004-2005 and 2012-2013 but fell away quite appreciably in the last 2 years of the period covered in the above table. These numbers were also reflected in the data on patenting activity in the sector, which we will discuss in a later section.

\subsection{Strategic Role of Standards}

The 2012 National Policy of India on Electronics deals with the development of Indian standards for technical quality and safety of electronic products. Ernst argued that technical standards are as important as patents for an economy. Technical standards contribute to productivity growth as it promotes diffusion of technological knowledge. A study conducted by the German Institute of Standardization found that $1 \%$ increase in stock of technical standards would contribute to $0.7-0.8 \%$ economic growth. ${ }^{24}$

\footnotetext{
${ }^{21}$ Ernst, Upgrading India's Electronics Manufacturing Industry, 2014, p. 15.

${ }^{22}$ ELCINA Country Report on the Indian Electronics Sector, 2007, p. 7 argues that substantial resources are yet to be allotted for semiconductor or chip manufacturing despite the modest government support since 1980s to cater for defence and communications.

${ }^{23}$ Prowess database includes all non-government companies with a market capitalisation of over Rs. 1 billion, a PE ratio between 5 and 10, a dividend yield of over 2 per cent and a debt/equity ratio of less than 1.

${ }^{24}$ K. Blind, A. Jungmittag, and A. Mangelsdorf (2011), The Economic Benefits of Standardization, German Institute for Standardization, quoted by Ernst (2014).
} 


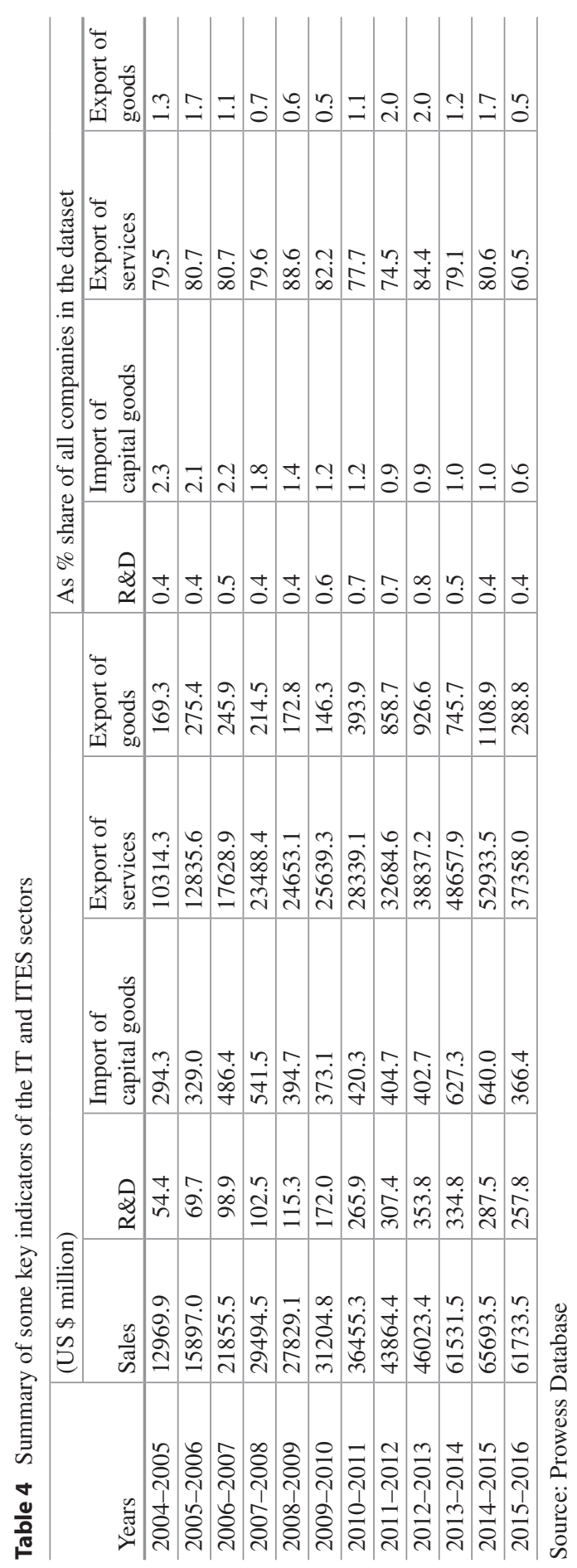


Standards are so vital a strategy in industrialisation for latecomers that Ernst called it their "lifeblood". Defining standards is a knowledge-intensive activity which involves cooperation between industry, government, academia and nongovernmental organisations representing larger interests of society. However, latecomers are often takers of standards rather than creators of standards, which adds to the vulnerability of their efforts to industrialise.

India's standardisation system is beset with a number of problems, stemming, in particular, from the presence of several standards development organisations (SDO), whose objectives, mandates and spheres of authority were often overlapping. For instance, the Quality Council of India is mandated to establish and operate national accreditation structure for bodies which confirm compliance of standards, while the National Accreditation Board for Testing Calibration Laboratories (NABL) provides accreditation to testing laboratories in accordance with ISO/IEC 17025. Besides, the National Accreditation Board for Certification Bodies (NABCB) recognises those bodies applying for accreditation based on the criteria set by NABCB. There are also a number of SDOs in the electronics sector - the Electronics and Information Technology Division Council of the Bureau of Indian Standards and Telecommunications Engineering Centre, the Global ICT Standardisation Forum for India.

\section{India's Information Technology-Enabled Services}

A convenient way of identifying the ITES is to refer to the classification provided by the General Agreement of Trade in Services of the World Trade Organization. ${ }^{25}$ According to this classification, the category of Computer and Related Services includes the following services: (i) consultancy services related to the installation of computer hardware; (ii) software implementation services; (iii) data processing services; (iv) database services; and (v) other related services. The following discussion would relate to the above-mentioned services.

\subsection{Evolution of the ITES Industry in India}

The ITES industry in India, currently one of the largest earners of foreign exchange, developed in three distinct phases. The industry emerged in the 1960s, and its export prospects were recognised as early as the early $1970 \mathrm{~s} .{ }^{26}$ The government adopted suitable policies to develop the export potential of this sector, the most important of which was to allow duty-free import of computer systems for software export purposes. One hundred percent foreign-owned enterprises were permitted, for software exports operations, in Santa Cruz Electronics Export Processing Zone (SEEPZ). ${ }^{27}$

\footnotetext{
${ }^{25}$ WTO (2001), Services Sectoral Classification List: Note by the Secretariat, MTN.GNS/W/120, 10 July 2001.

${ }^{26}$ Sharma (2015), Chapter 6.

${ }^{27}$ Department of Electronics (1972).
} 
The second phase follows the announcement of the New Electronics Policy and the New Computer Policy, both in 1984. In this phase, the most important development was the establishment of the software technology parks with government support that acted as the springboard for the consolidation of the software sector.

The third phase was ushered in by the Y2K problem (more on this in 2.5.). The ability of the Indian ITES sector to respond to the challenges posed by the Y2K heralded its presence in the global market.

\subsection{The Beginnings of a Global ITES Hub}

Although the Tata Consultancy Services (TCS) was the first enterprise to enter the industry in $1968,{ }^{28}$ the beginnings of this industry was made when pioneering professionals identified data conversion as the area in which jobs could be undertaken in India at a much cheaper cost, stemming from the low wage bill. ${ }^{29} \mathrm{By}$ the middle of the 1970s, the industry started taking a distinct shape. TCS collaborated with an American firm, Burroughs, resulting in the formation of the Tata-Burroughs. The early pioneers, too, had their own enterprise, the Patni Computer Systems (PCS). The SEEPZ, which began functioning in 1973-1974, led to the establishment of several ITES companies. ${ }^{30}$

By the 1970s, the demand was large enough for the entry of new companies like Infosys, which took over the reins of the industry in the subsequent period. However, much of their jobs were provided by foreign entities (mostly from the USA) as introduction of computers in India faced intense opposition. The buoyancy of the ITES industry was reflected in the steady increase of software exports from the mid1970s. From only Rs 8.50 million in 1975, software exports increased to Rs. 44 million in 1981. Within the next 5 years, software exports had jumped nearly fourfold to Rs 420 million. ${ }^{31}$

\subsection{Consolidation of the Industry Since the Mid-1980s}

As discussed earlier, the electronics industry went through rapid changes from the mid-1980s triggered by proactive government policies. The first of these was the slackening of government controls over the industry, which took place through the New Electronics Policy (NEP) of 1984. This was the precursor of the liberal economic policies adopted in the $1990 \mathrm{~s} .{ }^{32}$ Complementing the NEP was another important development that changed the future course of the software sector quite considerably. The Foreign Trade Policy for 1984-1985 contained a specific clause

\footnotetext{
${ }^{28}$ Patibandla et al. (2000).

${ }^{29}$ Sharma (2015), Chapter 6.

${ }^{30}$ Sharma (2015), Chapter 6.

${ }^{31}$ Lakha (1990), p. 50.

${ }^{32}$ Girdner (1987).
} 
that said: "software exports shall also be permitted through satellite-based data links with overseas computers". ${ }^{33}$ The significance of this policy change was felt soon after. In 1985, Texas Instruments (TI) became the first major firm to establish its presence in Bangalore where it set up a dedicated satellite link to connect with its offices in the United Kingdom and the USA.

The Policy on Computer Software Export, Software Development and Training announced in 1986 facilitated the development of the software industry. This policy underlined five key objectives: (i) software exports to achieve a quantum leap and obtain a sizeable share of the global software market; (ii) to target an integrated development of software for national and export markets; (iii) simplification of procedures in order to accelerate the growth in the industry; (iv) establishment of a firm base within the national software industry; and (v) increased utilisation of computers in decision-making and enhancing efficiency. ${ }^{34}$

The key strategy of the policy was "flood in, flood out", which meant that Indian firms were to be provided with advanced software and technology to enhance the international competitiveness of Indian exporters. ${ }^{35}$ To meet this strategy, licencing requirements were removed on software imports, and the import duty was reduced to $60 \%$ under the 1986 policy. This was further reduced to $25 \%$ for computers and software used by software producers in 1990. Additional measures for promotion of software exports include a $100 \%$ tax exemption to profits from software exports. ${ }^{36}$ Also, the specialised electronics Exports Processing Zones (EPZ) and other multiindustrial EPZs were set up in Bombay, Noida, Kandla, Calcutta, Madras and Kochi. ${ }^{37}$ All these measures resulted in a major boost to India's exports of software.

\subsection{Software Technology Parks and IT Clusters}

A proactive government took another major decision to facilitate the growth of the ITES sector in 1990 through the setting up of Software Technology Parks (STPs), allowing several software units to operate using shared communication links. The STPs provided the necessary infrastructure, including uninterrupted power supply to software companies. Most importantly, the STPs established satellite communication links that the software companies could use to develop software on the computers of their overseas clients from access terminals located in their respective premises in STPs. As the initial investment required to set up a software company was low, the STPs allowed many small entrepreneurs to enter the lucrative software export market. The first of the STPs were established in Bangalore 1990. Six more

\footnotetext{
${ }^{33}$ Sharma (2015), p. 163.

${ }^{34}$ Lakha (1990), p. 49.

${ }^{35}$ Parthasarathy (2004), Dedrick and Kraemer (1993).

${ }^{36}$ Dedrick and Kraemer (1993).

${ }^{37}$ Lakha (1990).
} 
STPs were set up under an umbrella organisation, the Software Technology Parks of India (STPI) controlled by the Department of Electronics. ${ }^{38}$

The advantages of locating units in STPs include single-window clearance system, tax holiday with no value addition requirements, and duty-free imports. In 2000, an STP was set up in Silicon Valley in the USA to facilitate exports by small and medium enterprises of India into the USA. ${ }^{39}$

\subsection{India as an ITES Leader in the New Millennium}

Two extraneous factors provided massive stimuli to the ITES sector in the new millennium. The first was the "millennium bug", the more common, Y2K problem. The new millennium posed an unexpected problem for the software as the programmes were not enabled to read the date in the new millennium. The second problem was to accommodate the emergence of the Euro as the currency of the single European Market. Accommodating the two changes involved labour-intensive processes, but the countries that had developed the programmes did not have the necessary manpower to fix the bug. The jobs had to be outsourced, and this provided an opportunity to the Indian software companies. Many of these companies secured their businesses by not only fixing the Y2K bug but also by providing subsequent improvements in the software, at no extra cost to the customers. ${ }^{40}$

The windfall made by the Indian companies can be gauged from the fact that between 1998-1999 and 2000-2001, software exports from India increased nearly 2.5 times in dollar terms. As a result, many software service companies entered the Fortune 500 list in the following years.

Over the past decade, the ITES industry had acquired a distinct character of its own by expanding at an unprecedented pace. Its presence in the global markets was particularly noteworthy. If the millennium had ended with the ITES industry exporting US $\$ 6$ billion, over the next decade, exports of this sector had expanded more than tenfold. India was given the epitaph "office of the world".

\subsection{Current Status}

ITES accounts for $90 \%$ of the IT industry in India, with hardware making up for the remaining $10 \%$ (Table 5).

India has more than 5000 ITES companies, with a maturity of more than 25 years. According to the A.T. Kearney Global Services Location Index (2014), India had topped the list of countries for "global off-shoring destination". ${ }^{41}$ The industry also moved from mere "body-shopping" (on-site service in export market) service

\footnotetext{
${ }^{38}$ Rajaraman (2012), p. 39.

${ }^{39}$ Kumar and Joseph (2004).

${ }^{40}$ Rajaraman (2012), p. 46.

${ }^{41}$ Malik and Velan (2016).
} 
Table 5 Indian IT industry in 2015 (US \$ billion)

\begin{tabular}{|c|c|c|c|c|c|c|}
\hline & \multicolumn{4}{|c|}{$\begin{array}{l}\text { Information technology and business process } \\
\text { management (BPM) industry } 2015\end{array}$} & \multirow[b]{2}{*}{$\begin{array}{l}\text { Electronics } \\
\text { hardware }\end{array}$} & \multirow[b]{2}{*}{$\begin{array}{l}\text { Total } \\
\text { (IT-BPM + } \\
\text { hardware) }\end{array}$} \\
\hline & IT services & BPM & $\begin{array}{l}\text { Packaged } \\
\text { software } \\
\text { (incl. R\&D) }\end{array}$ & $\begin{array}{l}\text { Total (excl. } \\
\text { hardware) }\end{array}$ & & \\
\hline World & 650 & 186 & 1884 & 2720 & 1075 & 2795 \\
\hline \multirow{2}{*}{$\begin{array}{l}\text { Indian IT } \\
\text { industry }\end{array}$} & 68.64 & 26.4 & 23.76 & 118.8 & 13.2 & 132 \\
\hline & $(52)^{\mathrm{a}}$ & $(20)^{\mathrm{a}}$ & $(19)^{\mathrm{a}}$ & $(90)^{\mathrm{a}}$ & $(10)^{\mathrm{a}}$ & $(100)^{\mathrm{a}}$ \\
\hline$\%$ in world & 10.56 & 14.19 & 1.26 & 4.36 & 1.22 & 4.72 \\
\hline $\begin{array}{l}\text { Indian IT } \\
\text { industry - } \\
\text { domestic } \\
\text { market }\end{array}$ & 13 & 3 & 4 & 20 & 13 & 33 \\
\hline $\begin{array}{l}\text { Indian IT } \\
\text { industry - } \\
\text { exports }\end{array}$ & 55.64 & 23.4 & 19.76 & 98.8 & 0.2 & 99 \\
\hline
\end{tabular}

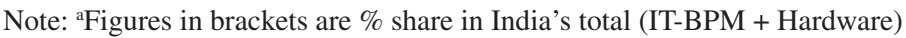

Source: Compiled by authors from NASSCOM (2016)

provider to producing "niche product market segments" by mid-1990s. Still, lower wages and lack of spending in R\&D kept the industry's productivity at a low level fuelled by excessive focus on low-end services. ${ }^{42}$ To move up the value chain, the industry needs to invest in $R \& D$ and provide effective intellectual property protection. ${ }^{43}$

\subsection{R\&D, Innovation and Intellectual Property Rights}

R\&D, innovation and intellectual property rights (IPRs) are areas in which most studies on ITES industry are not adequately focused. Among the few studies that do consider these areas, Kumar and Joseph argued that the weak India's copyright regime facilitated proliferation of software piracy, which in turn acted as disincentive for firms to develop software products. ${ }^{44}$ The study does not make it clear as to whether piracy resulted from deficiencies in law or on account of lax enforcement.

Basant and Mani analysed the patenting behaviour of foreign R\&D centres and concluded that "India has fair amount of innovation capability in the ICT software and in some cases in hardware too" ${ }^{45}$ They based their conclusion on the patenting activities of foreign companies located in India. The ICT firms had a share of $86 \%$ of the total 1969 patents which were granted to the 59 firms during the period between 2006 and 2010. Basant and Mani excluded "electronics and medical

\footnotetext{
${ }^{42}$ Mukherjee (2016).

${ }^{43}$ Patibandla et al. (2000).

${ }^{44}$ Kumar and Joseph (2004).

${ }^{45}$ Basant and Mani (2012), p. 19.
} 
devices" from the category of ICT. If these firms are included in the category of ICT firms, the share of ICT firms in total number of patents granted increases to $95 \%$. This indicates that foreign R\&D activities are concentrated in ICT.

R\&D operations in India accounted for $46 \%$ of total patents granted by multinational companies (MNCs) such as Symantec. MNCs are keen to operate R\&D centres in India as the cost of R\&D professionals in India is much lower; wage advantage drives investment into R\&D in India. Basant and Mani also surveyed R\&D centres operated by foreign firms in India and found (a) utilising human resources in India was the most important motive for foreign investment. Another important motive was development of new technologies for world market rather than for adapting their products to Indian market, (b) basic research and new product development is the relatively more important type of R\&D activity, and (c) focus of R\&D in India was on research that can be used immediately, long-term research had low priority. ${ }^{46}$

Another important observation made by Basant and Mani, is that "while India focuses on pharmaceuticals and chemistry related technologies, China has an important share of electronics and telecommunications, areas that are more amenable to design innovations". ${ }^{47}$ This means that intellectual property protected under designs law could be an indicator for innovations in the ITES sector, especially in the hardware sector. None of the studies reviewed here considered design innovations. Annual Report 2014-2015 of the Office of Controller General of Patents, Designs, Trademarks and Geographical Indications (CG Office) reports that while the share of Indian applicants in patents is only $28 \%$, their share in design applications is $70 \%$. This probably indicates that India has strengths in design innovations.

\section{$4 \quad$ Patentability of Computer-Related Inventions in India}

Prior to the second amendment of Patents Act, 1970, that was undertaken for making it compatible with the Agreement on Trade-Related Aspects of Intellectual Property Rights (TRIPS), there were no explicit exclusions in the statute for inventions in the field of CRI. ${ }^{48}$ "Invention" was defined under Section 2.1(j) of the Act as "any new and useful (i) art, process, method or manner of manufacture; (ii) machine, apparatus or other article; (iii) substance produced by manufacture. CRIs could be patented like inventions in all areas which could be patented upon fulfilment of the novelty and usefulness criteria. ${ }^{49}$ Inventions relating to "methods" or "processes" were limited to "manner of manufacture". For a "method" to be considered patentable, it had to undergo the scrutiny of whether or not it is a "manner of

\footnotetext{
${ }^{46}$ Basant and Mani.

${ }^{47}$ Basant and Mani (2012), p. 17.

${ }^{48}$ The term has been used by the CG Office while providing the guidelines for the examination of patents.

${ }^{49}$ CG Office 2013 Guidelines for Examination of Computer Related Inventions (CRIs). p. 4.
} 
manufacture". Subject matters relating to mental acts, mathematical methods, business methods, algorithms and computer programmes were not covered by the category, "manner of manufacture", and were hence not considered as inventions under the statute and were therefore not patentable.

This unambiguous application of India's patent law to CRIs has changed significantly since the adoption of the second amendment of Patents Act, 1970. While the regime for patenting computer hardware followed the standards set by the TRIPS Agreement, India adopted its own patenting standards as regards computer programmes. The Patent (Second Amendment) Bill introduced in 1999 proposed in its amendment of Section 3 of the Patents Act dealing with exclusions from patentability, a new Section 3(k), which reads that "a mathematical or business method or a computer program or algorithms" were not inventions and hence not patentable. Thus, while the Patents Act was silent about patentability of computer programmes or software, the amendment Bill disallowed patenting of all mathematical or business methods, computer programmes and algorithms.

However, the Joint Parliamentary Committee (JPC) of the Indian Parliament to which the Bill was referred to took a different view of the proposed Section 3(k). In its recommendations, the JPC rejected the complete exclusion of computer programmes from being patented, and it did so by inserting the words "per se".

\subsection{Yardsticks Followed by the CG Office to Deal with Section 3(k)}

Applicability of the provisions of Section 3(k) of the Patents Act, 1970, has been detailed by the Manual of Patent Practice and Procedure ("Patent Manual") and the Guidelines for the Examination of Computer Related Inventions (“Guidelines").

\subsubsection{The 2013 Guidelines}

Since 2013, the CG Office has been issuing Guidelines that have dwelled on the approaches patent examiners could adopt on this vexed issue. The first set of Guidelines pointed out that applications relating to CRIs could be included under the following three categories: (i) method/process, (ii) apparatus/system, and (iii) computer programme product. ${ }^{50}$

According to the Guidelines, claims relating to mathematical method or business method or computer programme per se or algorithm or mental act are claimed in "method/process" format. The Guidelines stated that patent examiners have a very critical role in ascertaining whether the invention belongs to one of such categories and hence falls under excluded subject matter. This view implies that an element of ambiguity is involved in the patenting of methods and processes.

The Guidelines allude to the fact that claims involving apparatus/system requires the examiners to properly construe whether the claimed subject matter relates to any apparatus which is novel, inventive, having industrial applicability or is just

${ }^{50}$ CG Office 2013. Guidelines for Examination of Computer Related Inventions (CRIs). p. 12-16. 
formatted to appear so. The apparatus claim should clearly define the inventive constructional/hardware features. The claim for an apparatus may incorporate a "process limitation" for an apparatus, where "limitation" means defining the specific application and not the general application.

Claims relating to computer programmes product that are nothing but computer programme per se simply expressed on a computer readable storage medium and are as such not allowable. However, the Guidelines argue that the scope of the exclusion of computer programmes from the ambit of Patents Act, 1970, or, in other words, the remit of exclusion defined by the phrase "computer programme per se" needs careful consideration by patent examiners.

The question, according to the Guidelines, is whether a computer programme loaded on a general-purpose computer or related devices can be patented. While the spirit of law should lead to an answer in the negative, in an application for patent for a new hardware system, the possibility of a computer programme forming part of the claims cannot be ruled out. In this case, too, the examiner has to carefully consider as to how integrated is the novel hardware with the computer programme. A further consideration for the examiners is whether the machine is programme specific or the programme is machine specific.

The Guidelines suggested that patentability of computer programmes should be assessed in combination with the features of the relevant hardware; the hardware must be something more than general-purpose machine. In cases where the novelty resides in the device, the machine or the apparatus and if such devices are claimed in combination with the novel or known computer programmes to make their functionality definitive, the claims relating to these devices may be considered patentable, but only if the invention can pass the triple test of novelty, inventive step and industrial applicability. ${ }^{51}$

\subsubsection{The 2015 Guidelines}

If the Guidelines issued in 2013 had given indications of the possibilities of computer programmes to be patented through creative interpretations that could be used to work around the phrase "computer programme per se", the following set of Guidelines issued in 2015 pushed the possibilities further. ${ }^{52}$ The 2015 Guidelines clarified that in order to be patentable, CRIs must have (i) novel hardware, (ii) novel hardware with a novel computer programmes or (iii) novel computer programmes with a known hardware which can go beyond the normal interaction with such hardware and can affect a change in the functionality and/or performance of the existing hardware. Based on the above criteria, the 2015 Guidelines stated that computer programmes, when running on or loaded into a computer, going beyond the "normal" physical interactions between the software and the hardware on which it is run, and is capable of bringing further technical effect, may not be considered as exclusion under these provisions.

\footnotetext{
${ }^{51}$ CG Office 2013. Guidelines for Examination of Computer Related Inventions (CRIs). p. 19-21.

${ }^{52}$ CG Office 2015. Guidelines for Examination of Computer Related Inventions (CRIs). p. 13.
} 
The 2015 Guidelines suggested that while examining CRI applications, the examiner must confirm that the claims have the requisite technical advancement. An indicative list of questions was provided using which the examiner could determine the technical advancement of the CRIs. These were ${ }^{53}$ :

(i) Whether the claimed technical feature had a technical contribution on a process which was carried on outside the computer

(ii) Whether the claimed technical feature operated at the level of the architecture of the computer

(iii) Whether the technical contribution was in the nature of change in the hardware or the functionality of hardware

(iv) Whether the claimed technical contribution resulted in the computer operating in a new way

(v) Whether the programme made the computer a better computer, i.e. running more efficiently and effectively, in case of a computer programme linked with hardware

(vi) Whether the change in the hardware or the functionality of hardware amounted to technical advancement

If answer to any of the above questions was in affirmative, the Guidelines suggested that the invention may not be considered as exclusion under Section 3(k) of the Patents Act, 1970.

\subsubsection{The 2017 Guidelines}

The latest set of Guidelines, issued in March 2017, while providing further clarity to the patentability of computer programmes, raised questions regarding the scope of exclusion of Section 3(k).

The Guidelines pointed to the fact that patents on computer programmes are often claimed in the form of method claims or system claims with some "means" indicating the functions of flow charts or process steps. Algorithm-related claims are much wider than the computer-programme claims as a single algorithm can be implemented through different programmes in different computer languages. If claims in any form, including methods or processes, or apparatus, systems or devices, or computer programme product or computer readable medium, belong to the excluded categories, they cannot be patentable. ${ }^{54}$

As regards the exclusion of "computer programme per se", the Guidelines suggest that it is important to ascertain from the nature of the claimed CRI whether the invention is of a technical nature involving technical advancement as compared to the existing knowledge or having economic significance or both.

The 2017 Guidelines clarify that patent claims which are directed towards computer programmes per se are excluded from patentability, such as (i) claims directed at computer programmes/set of instructions/routines and/or subroutines and (ii)

\footnotetext{
${ }^{53}$ CG Office 2015. Guidelines for Examination of Computer Related Inventions (CRIs). p. 13-14. ${ }^{54}$ CG Office 2017. Guidelines for Examination of Computer Related Inventions (CRIs). p. 13-14.
} 
claims directed at "computer programme products"/"Storage Medium having instr uctions"/“Database"/“Computer Memory with instruction" stored in a computer readable medium.

Although Section 3(k) excludes algorithms from patentability, the Guidelines point out that computer programmes are often claimed in the form of algorithms as method claims or system claims with some "means" indicating the functions of flow charts or process steps. A suggestion is therefore made that while establishing patentability, the focus should be on the underlying substance of the invention and not on the particular form in which it is claimed.

According to the new Guidelines, mere presence of a mathematical formula in a claim, to clearly specify the scope of protection being sought in an invention, does not make it a claim involving a "mathematical method". However, such exclusion may not apply to inventions that include mathematical formulae and resulting in systems for encoding, reducing noise in communications/electrical/electronic systems or encrypting/decrypting electronic communications.

The above discussion indicates that over the past decade and a half since the adoption of the second amendment of the Patents Act, 1970, the CG Office has tried to provide a degree of clarity over the critical issue of patenting computer software. The efforts of the CG Office have been complemented in recent years by the Courts that have adjudicated the cases involving FRAND (fair, reasonable and nondiscriminatory) licences between the telecom companies. Brief accounts of the two judgements which referred to the patenting of computer programmes are given below.

\subsection{Court Decisions on Patenting of Computer Programmes}

Over the past few years, the High Court of Delhi has passed its orders in two cases, both of which were petitioned by the global telecom giant, Ericsson, against the violation of its patents registered in India.

In the first case involving Ericsson and Intex Technologies, the Court, in its interim judgement, ${ }^{55}$ provided a new interpretation of the exclusions provided under Sections 3(k). In the dispute, Intex Technologies argued that Ericsson's patents were computer programmes and were hence not patentable. The Court observed that the novelty and inventive step of the disputed Ericsson patent lay in an encoder specifically developed and designed by the company. In order to perform its functions, the encoder required several hardware components. The fact that while performing these functions certain predetermined guidelines are followed does not mean that the claimed invention is a mere algorithm or computer

${ }^{55}$ Telefonaktiebolaget Lm Ericsson V. Intex Technologies (India) Ltd., IA No. 6735/2014 in CS (OS) No. 1045/2014, judgement delivered on 13 March 2015, p. 133.34. 
programme per se. The Court added that Ericsson mentioned the term "algorithm" in the complete specification, which was a "search algorithm" used for determining the best mode of transmitting the signals. Mere reference to the use of a "procedure" or a "method" or an "algorithm" in an apparatus, which comprised of various network or hardware elements so as to bring about a technical effect or to perform a technical process did not reduce the claimed invention an algorithm or computer programme per se or even a mathematical method or formula as contemplated under Section 3(k) of Patents Act, 1970.

In the second case in which Ericsson similarly litigated Lava International Ltd. over violation of its patents by the latter, the High Court of Delhi ruled that Lava's assertions that an encoder used in Ericsson's technology was a mere mathematical method or an algorithm is misleading. Encoder and decoder are practical realisations of a speech coding and decoding method with a physical effect and as such were much more than just an algorithm. Mere mention of an algorithm or a mathematical formula in a patent document should not be inferred to mean that the invention is nothing but an algorithm. ${ }^{56}$

These decisions by the Court, together with the progressively refined interpretations given by the CG Office, will ensure that Section 3(k) is implemented in its letter and spirit. More importantly, the inventor would be encouraged to file for patents in India, especially on software innovations.

The trends in patent grants in computer hardware and computer programmes in India are presented in Tables 6 and 7. The trends capture the essence of patenting standards that exist in the two domains. Table 6 shows that the patent grants in

Table 6 Patents granted in India on computer/electronics

\begin{tabular}{l|l|l|l}
\hline Years & $\begin{array}{l}\text { Total number of } \\
\text { patents granted }\end{array}$ & $\begin{array}{l}\text { Patents granted in } \\
\text { computer/electronics }\end{array}$ & $\begin{array}{l}\text { Share of computer/electronics } \\
\text { in total granted patents }(\%)\end{array}$ \\
\hline $2006-2007$ & 7539 & 237 & 3.1 \\
\hline $2007-2008$ & 15,316 & 1357 & 8.9 \\
\hline $2008-2009$ & 16,061 & 1913 & 11.9 \\
\hline $2009-2010$ & 6168 & 1195 & 19.4 \\
\hline $2010-2011$ & 7509 & 892 & 11.9 \\
\hline $2011-2012$ & 4381 & 584 & 13.3 \\
\hline $2012-2013$ & 4126 & 510 & 12.4 \\
\hline $2013-2014$ & 4226 & 690 & 16.3 \\
\hline $2014-2015$ & 5978 & 835 & 14.0 \\
\hline $2015-2016$ & 6326 & 810 & 12.8 \\
\hline
\end{tabular}

Source: Annual Reports, CG Office, Government of India

\footnotetext{
${ }^{56}$ Telefonktiebolaget LM Ericsson v. Lava International Ltd. 2016. CS (OS) 764/2015, judgement pronounced on 10 June, 2016. p. 52.
} 


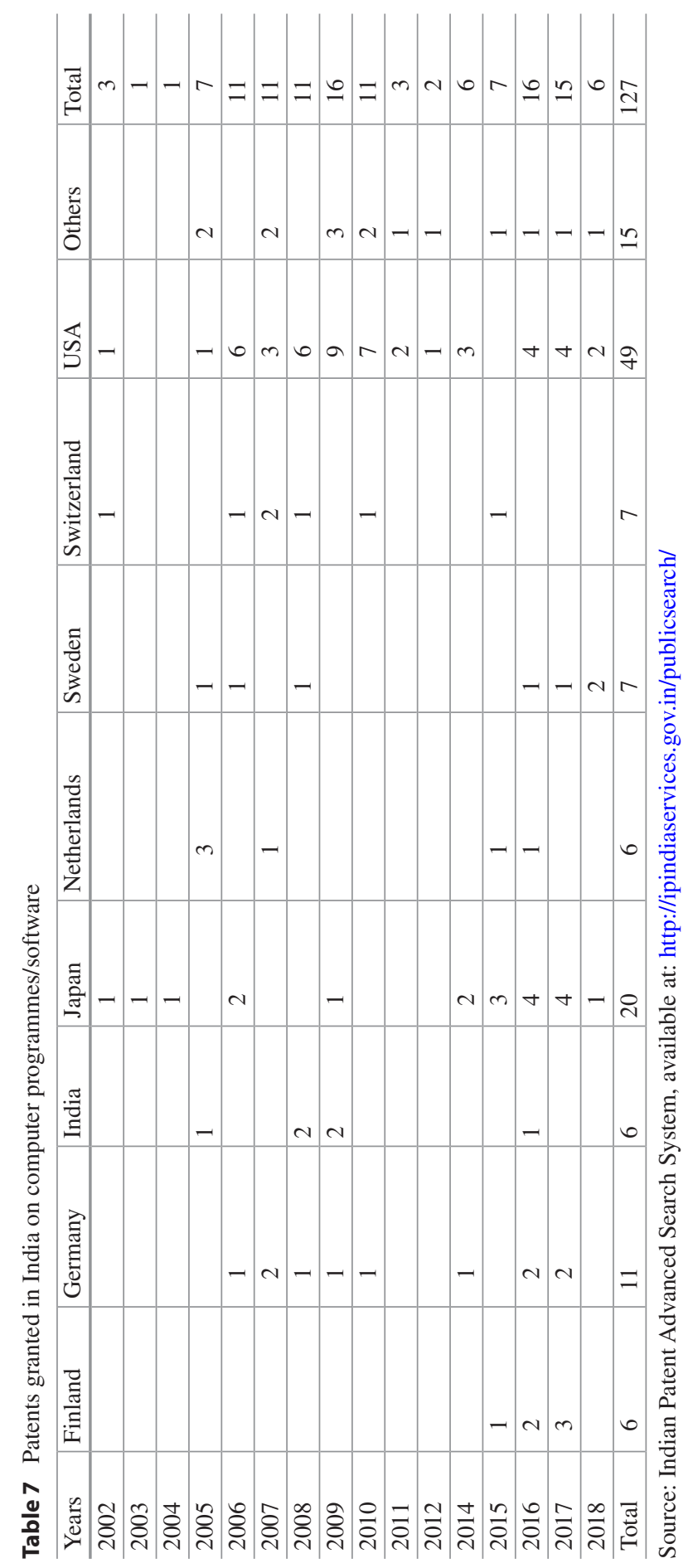


computer hardware have been within a range in most of the years for which data are presented. This is possibly a reflection of the fact that patentability standards offered by India's patents regime to innovators in hardware are relatively more predictable than in the case of computer programmes.

Patent grants on computer programmes, including software (Table 7), show an interesting trend. In the previous decade, when there was lack of clarity regarding the interpretation of the contentious phrase, "computer programme per se" in Section 3(k) of Patents Act, 1970, software patents were being granted. However, in the subsequent period, which is the period that saw considerable efforts being made to interpret the contentious phrase by the CG Office and the Courts, only one computer programme has been patented.

\section{$5 \quad$ By Way of Conclusions}

The objective of this chapter was to provide an account of the development of the IT and ITES in India. The first part of the study that focused on the development of the industry until the 1990s traced the origins of the two sectors. The IT sector developed under government controls, wherein only the government-owned companies were allowed to expand in this sector. In contrast, the ITES sector was mostly developed through private initiatives, the non-resident Indians, in particular.

By the 1980s, it became clear that the model for the growth of the IT sector adopted by the government through its own entities was a non-starter. The policy framework for the expansion of the industry was completely changed with the government inviting foreign players to take the lead. In fact, the IT sector became the first sector, which was opened for foreign investment well before the government officially adopted the policy of economic reforms in early 1990s.

During the period of economic reforms, the government chose the path of rapid opening of the sector. India was one of the few developing countries that endorsed the Information Technology Agreement in 1997, whose objective was to eliminate tariffs on IT products.

There is no evidence that this open-door policy helped the IT industry to develop. In contrast, the ITES sector received a major boost when Indian companies were able to take advantage of the increasing demand for these services towards the end of the previous millennium. Subsequently, the ITES has expanded phenomenally, establishing India as one of the ITES powerhouses of the world.

Although India's ITES sector was an unqualified success, there is not much evidence that this sector, or its hardware counterpart, showed any dynamism in the realm of technology development. India's R\&D spending remained sluggish, a major source of concern.

One uncertainty faced by the R\&D system was India's patent regime. In the second amendment of the Patents Act, 1970, undertaken to make India's patent law conform to the TRIPS Agreement, "computer programme per se" was excluded from patenting. There was complete lack of clarity as to the interpretation of the phrase. However, in the more recent years, both the Controller General of Patents, 
Designs and Trademarks and the Courts are providing a degree of conceptual clarity as to what "computer programme per se" really means.

Our study has shown that India's IT and ITES sectors face considerable challenges as the government has taken a series of step to enhance the level of integration of the Indian economy with its partners. Our analysis has shown that there are significant deficiencies in the two sectors, especially in their abilities to put forward efficient innovation systems, which would have to be addressed for them to compete meaningfully in the global markets.

\section{References}

Agarwal, S. M. (1985). Electronics in India: Strategies and future possibilities. World Development, 13(3), 273-292.

Basant, R., \& Mani, S. (2012). Foreign R\&D centres in India: An analysis of their size, structure and implications (Working Paper No. 2012-01-06). IIM Ahmedabad.

Brunner, H.-P. (1991). Building technological capacity: A case study of the computer industry in India, 1975-87. World Development, 19(12), 1742.

Dedrick, J., \& Kraemer, K. L. (1993). Information technology in India: The quest for self-reliance. Asian Survey, 33(5), 463-492.

Department of Electronics. (1972). Annual report, New Delhi, in Kumar and Joseph (2004).

ELCINA. (2007). Country report on the Indian electronics sector. New Delhi: Electronic Industries Association of India.

Ernst, D. (2014). Upgrading India's electronics manufacturing industry: Regulatory reform and industrial policy. Honolulu: East-West Centre.

Francis, S. (2016). Impact of trade liberalization on the Indian electronics industry: Some aspects of industrial policy dynamics of global value chain engagement (Working Paper No. 192). Institute for Studies in Industrial Development, New Delhi.

Girdner, E. J. (1987). Economic liberalization in India: The new electronics policy. Asian Survey, 27(11), 1188-1204.

Grieco, J. M. (1982, Summer). Between dependency and autonomy: India's experience with the international computer industry. International Organization, 36(3), 609-632.

Karunakaran, N. (2009, May 16). God, man and machine. Outlook Business. Accessed from: http://archive.outlookbusiness.com/article_v3.aspx?artid=102117

Kumar, N., \& Joseph, K. J. (2004). National innovation systems and India's ICT capability: Are there any lessons for ASEAN newcomers? (RIS Discussion Paper 72/2004). New Delhi.

Lakha, S. (1990, January 6). Growth of computer software industry in India. Economic and Political Weekly XXV(1), 49-51+53-56.

Malik, M. H., \& Velan, N. (2016). Trends and determinants of IT-BPM exports in India. Journal of Science and Technology Policy Management, 7(2), 212-232.

Mrinalini, N., Nath, P., \& Sandhya, G. D. (2013). Foreign direct investment in R\&D in India. Current Science, 105(6), 767-773.

Mukherjee, A. (2016, October 14). Indian software dies at 17 from failure to grasp future, Live Mint. http://www.livemint.com/Opinion/737W8zcjPA61GWIajRCd6K/Indian-software-diesat-17-from-failure-to-grasp-future.html

NASSCOM. (2016). Information technology strategic report 2016, executive summary. New Delhi.

Parthasarathy, B. (2004). Globalizing information technology: The domestic policy context for India's software production and exports. Iteration: An Interdisciplinary Journal of Software History, 3, 1-38.

Patibandla, M., Kapur, D., \& Petersen, B. (2000). Import substitution with free trade: Case of India's software industry. Economic and Political Weekly, 35(15), 1263-1270. 
Rajaraman, V. (2012). History of computing in India (1955-2010). Bangalore: Supercomputer Education and Research Centre, Indian Institute of Science.

Rao, C., \& Dhar, B. (2016, December). The tenuous relationship between make in India and FDI inflows (ISID Policy Brief No. 2).

Reserve Bank of India. (2010, March). Invisibles in India's balance of payments: An analysis of trade in services, remittances and income. Reserve Bank of India Monthly Bulletin. Accessed from https://www.rbi.org.in/scripts/BS_PressReleaseDisplay.aspx?prid=4251381, on 1 March 2018.

Reserve Bank of India. (2017). Survey on computer software \& information technology enabled services exports: 2016-17 - Data Release.

Sharma, D. C. (2015). The outsourcer: The story of India's IT revolution. Cambridge, MA: MIT Press/Harvard.

WTO. (2001). Services Sectoral Classification List: Note by the Secretariat, MTN.GNS/W/120, 10 July.

Open Access This chapter is licensed under the terms of the Creative Commons Attribution 4.0 International License (http://creativecommons.org/licenses/by/4.0/), which permits use, sharing, adaptation, distribution and reproduction in any medium or format, as long as you give appropriate credit to the original author(s) and the source, provide a link to the Creative Commons license and indicate if changes were made.

The images or other third party material in this chapter are included in the chapter's Creative Commons license, unless indicated otherwise in a credit line to the material. If material is not included in the chapter's Creative Commons license and your intended use is not permitted by statutory regulation or exceeds the permitted use, you will need to obtain permission directly from the copyright holder. 